\title{
El destierro de la sentimentalidad lírica aurisecular en los sonetos amorosos de Torres Villarroel
}

Ignacio García Aguilar Universidad de Córdoba

CES.XVIII, núm. 25 (2015), págs. 97-128. 


\begin{abstract}
Resumen
El propósito de este trabajo es estudiar los sonetos amorosos de Torres Villarroel impresos en su poemario Entretenimientos del numen (1738). Aunque la bibliografía crítica concluye que este autor imitó la poesía aurisecular en sus escritos, después de analizar sus sonetos amorosos se puede asumir que el poeta se aleja de la tradición previa ofreciendo un modelo crítico para explorar y reescribir la poesía española del Siglo de Oro. Esta ruptura con la tradición previa se puede apreciar en varias de las innovaciones que presentan sus sonetos, tales como la construcción de una nueva sentimentalidad lírica, una atención sin precedentes a la realidad empírica, así como la incorporación a su discurso poético amoroso de algunas de las ideas ilustradas de Feijoo.
\end{abstract}

Palabras clave

Torres Villarroel, poesía amorosa, Entretenimientos del numen.

ABSTRac

The purpose of this paper is to study Torres Villarroel love sonnets printed in his book of poems Numen Entertainments (1738). Though the critical bibliography concludes that this author imitated Golden Age poetry in his works, after analyzing Torres Villarroel love sonnets it can be assumed that the poet moves away from the previous tradition providing a critical model for exploring and rewriting Spanish Golden Age poetry. This break with the previous tradition can be seen in several of his sonnets innovations, such as the construction of a new lyrical sentimentality, an unprecedent attention for the empirical reality, as well as the assimilitation of several Feijoo's Enlightenment ideas into his love poetical discourse.

KEYWORDS

Torres Villarroel, love poetry, Numen Entertainments.

Recibido: 16 de junio de 2015. Aceptado: 14 de septiembre de 2015. 
Los Sonetos amorosos de Torres Villarroel: hacia una nueva sentimentalidad

Diego de Torres Villarroel fue entre sus contemporáneos un escritor tan denostado como elogiado. Autor de una amplísima producción, publicó en vida casi ciento cincuenta obras de naturaleza muy heterogénea, lo que es bien indicativo de su aceptación mayoritaria en el mercado del libro ${ }^{1}$, así como de su apuesta personal por la profesión literaria. Su obra ha sido estudiada con rigor y profundidad desigual, pues se ha prestado una atención prioritaria a las que fueron sus más fecundas y exitosas creaciones: la prosa de ficción y, sobre todo, los pronósticos. Los poemas del Piscator, sin embargo, no han despertado demasiado interés en la historiografía literaria ${ }^{2}$, y ello a pesar de que fue autor de un notable número de versos que fatigaron los espacios de socialización habituales para la poesía dieciochesca: desde lo efímero ocasional, académico o festivo hasta la fijación sobre la página del poemario impreso ${ }^{3}$.

La primera recopilación de poesía publicada en vida por Torres Villarroel, y en cuya conformación participó activamente, data de 1738 y vio la luz en Salamanca, con el título de Juguetes de Talía, entretenimientos del numen. El libro

1 Para un listado exhaustivo de las obras impresas de Villarroel véase el apéndice bibliográfico de Guy Mercadier en Diego de Torres Villarroel. Máscaras y espejos, ed. Manuel María Pérez López, Salamanca, Edifsa, 2009.

2 Con alguna excepción, como los trabajos básicos de Luis LóPEz MoLinA, «Torres Villarroel, poeta gongorino», Revista de Filología Española, 54.1/2 (1971), págs. 123-143; Alberto Navarro, «Don Diego de Torres Villarroel, poeta catedrático de la Universidad de Salamanca», en AA. VV., Una figura salmantina. Don Diego de Torres Villarroel, Salamanca, Artes Gráficas Europa, 1971, págs. 15-28 y Guy MERCADIER, «Diego de Torres Villarroel, animateur d'une joute poétique (Présentation d'un autographe inédit)», en AA. VV., Hommage a André Joucla-Ruau, Aix-en-Provence, Université de Provence, 1974, págs. 138-145. A estos trabajos se pueden sumar las ediciones de John Polt, Poesía del siglo XvIII, Madrid, Castalia, 1975, págs. 66-77 y Rogelio Reyes, Poesía española del siglo XVIII, Madrid, Cátedra, 1988, págs. 68-74. Hace ya un cuarto de siglo que Emilio Martínez Mata señaló como tarea pendiente el estudio de la poesía torresiana, con palabras que reflejan un consenso crítico de entonces y también del día de hoy: «Queda, pues, mucho por hacer. Su poesía, aparte de los trabajos citados de López Molina y Mercadier y del de Alberto Navarro, necesita un pormenorizado examen que ponga de relive no solo sus deudas con Góngora o Quevedo, sino también sus cualidades» (Emilio Martínez Mata, Los «Sueños» de Diego de Torres Villarroel, Salamanca, Ediciones Universidad de Salamanca-Instituto Feijoo de Estudios del Siglo XVIII, 1990, pág. 13).

3 Para el espacio de la poesía en las formas de sociablidad del Bajo Barroco véase el monográfico coordinado por Jean-Marc Buiguès, Poésie et société en Espagne: 1650-1750, publicado en Bulletin Hispanique 115.1 (2013). 
se estampó en la ciudad en la que el Piscator ejerció como catedrático y en unas fechas particularmente interesantes en el itinerario profesional y vital del autor. De acuerdo con la periodización establecida por Mercadier para estudiar la biografía de Villarroel, importa destacar que el volumen poético se imprime justo al comienzo del cuarto período de su decurso vital, el que transcurre entre los años 1738 y 1751. Es esta una etapa bastante oscura y desconocida, debido en gran medida a que el propio Villarroel no aporta nada en su Vida (1743) sobre los años comprendidos entre 1738 y $1743^{4}$.

Atendiendo al contexto epocal más amplio en que se imprimen los versos del salmantino, conviene considerar dos cuestiones que nos parecen de especial relevancia para comprender el estado en que se encontraba la reflexión e innovación literaria, y particularmente la poética, en el momento en que Villarroel decide publicar su primera recopilación de poesía. En primer lugar, no debe pasarse por alto que los Juguetes ven la luz un año después de la primera edición de la Poética de Luzán, donde se plantea, entre otras muchas cuestiones, que la poesía lírica vulgar puede ser útil; y para justificarlo se establece una división entre poetas lascivos, los cuales son deshechados sin remisión, y los poetas amorosos, que no son denostables en todos los $\operatorname{casos}^{5}$. La poesía amorosa, por tanto, era susceptible de ser considerada como una modalidad discursiva útil y provechosa desde la preceptiva neoclásica. Si reparamos en este hecho es porque Villarroel alberga en sus Juguetes una importante cantidad de sonetos amorosos, a los que nos referiremos en las páginas siguientes.

En segundo lugar, existe otra circunstancia que nos parece de interés en relación al análisis que nos proponemos, y tiene que ver con el hecho de que los Juguetes de Talía son publicados apenas dos años después de que se hubiese estampado el séptimo volumen del Teatro Crítico Universal de Feijoo. Esta obra, como es bien sabido, comenzó a imprimirse en la década de los veinte y se continuó estampando durante los años posteriores, hasta finales de la década de los treinta. Para el caso que nos ocupa tiene singular importancia lo que expone Feijoo en los dos últimos discursos del volumen séptimo («Causas del amor» $\mathrm{y}$ «Remedios del amor $»^{\circ}$ ) acerca del enamoramiento y de las soluciones para curar esta pasión. Aunque más adelante nos detendremos en ciertos aspectos de los Remedios des-

4 Véase sobre esto Diego de Torres Villarroel, Vida, ed. Guy Mercadier, Madrid, Castalia, 1972, en donde el estudioso delimita los cinco períodos que se consideran representativos de la biografía torresiana: 1694-1720, 1721-1726, 1727-1737, 1738-1751 у 1752-1770.

5 Ignacio de LuZán, La poética, o reglas de la poesía en general, y de sus principales especies, ed. Russell P. Sebold, Barcelona, Labor, 1977, págs. 193-195. Sobre esta cuestión y sus implicaciones en la dicotomía docere-delectare, véase José Checa BeLtrán, Razones del buen gusto (poética española del Neoclasicismo), Madrid, CSIC, 1998, págs. 117-119.

6 «Causas del amor», Discurso XV, y «Remedios del amor», Discurso XVI. 
critos por el ilustrado español y sus posibles vínculos con la poesía torresiana, importa subrayar ahora que la delimitación de este problema relacionado con la expresión de emociones individuales, así como los argumentos planteados para su resolución, resultan indicativos, a nuestro juicio, de la progresiva conformación de un nuevo paradigma sobre el amor y la sentimentalidad que se basa en la reformulación de las auctoritates clásicas y de los modelos previos, lo que se conjuga con una indagación crítica y racional apegada a la realidad empírica.

Ambas obras, la de Feijoo y la de Luzán, son sintomáticas de un contexto general de cambio marcado por la paulatina ruptura con la tradición heredada, un mayor interés por lo racional y un general apego hacia la realidad observable. El Piscator no daba por completo la espalda a este proceso en ciernes, como se comprueba con su Anatomía, en donde una pequeña luz de racionalidad comienza a abrirse paso por entre las sombras de la superstición (si bien es cierto que de modo desigual a lo largo del volumen, lo que ha suscitado no pocas opiniones contrarias a aceptar elementos de innovación en la obra) ${ }^{7}$. Además de esto, lo ya apuntado sobre la utilidad de la poesía en Luzán, que pasa por lo amoroso en contraposición a lo lascivo, y el sentido racional con que Feijoo trata de exponer las causas del enamoramiento y sus remedios, permiten asumir que se estaba produciendo una particular revisión de los temas y motivos propios del discurso amoroso, en donde la razón tenía cada vez un mayor peso. De acuerdo con todo esto, se puede intuir que la manera en la que se formule la nueva sentimentalidad será el resultado de la tensión entre el repertorio precedente y las incipientes formas de pensamiento ilustrado.

Torres Villarroel no era ajeno a las complejidades del sistema literario de su tiempo al publicar los Juguetes, pues conocía el Teatro crítico de Feijoo, como prueban las diversas invectivas que le había dirigido desde la década de los veinte ${ }^{8}$;

\footnotetext{
7 Pérez López explica que la Anatomía es «su primer libro ambicioso». En él, Torres Villarroel «traduce a síntesis divulgadora el modelo tradicional de los compendia o enciclopedias científicas. Es anacrónico sorprenderse de que acoja materiales escolásticos tan "científicos" como ángeles, demonios y brujas (presentes en los modelos a su alcance, como el Compendium Philosophicorum de Tosca y las obras de Athanasius Kircher Iter exstaticum y Mundus subterraneus), o escandalizarse de que acate el geocentrismo. Lo que desde nuestra perspectiva llama la atención son sus frecuentes gestos de disidencia: sus proclamaciones de empirismo, su adhesión al atomismo, sus guiños distanciadores frente a los excesos anticientíficos del magisterio escolástico, sus referencias al sistema copernicano en términos idénticos a los novadores» (Manuel María PÉREz LóPEz, «Para una revisión de Torres Villarroel», en Manuel María Pérez López y Emilio Martínez Mata, Revisión de Torres Villarroel, Salamanca, Ediciones Universidad de Salamanca, 1998, págs. 13-35, en pág. 21). Por su parte, Rodríguez de la Flor lo define como «un tratado racionalizador y logicista» que se instala «en la fisura que existe entre las dos concepciones del mundo refractarias una a la otra: la magia (y la religión) y la ciencia» (Fernando Rodríguez DE LA FLOR, «El discurso del duende en los momentos inaugurales del periodo novator», Criticón, 103-104 (2008), págs. 153-169, en págs. 157-158.

8 Diego de Torres Villarroel, Posdatas de Torres a Martínez, en la respuesta a don Juan Barroso sobre la carta defensiva que escribió al reverendísimo padre fray Benito Feijoo, y en ellas explica el globo de luz o
} 
y también debería de conocer los nuevos aires preceptistas de la poética de Luzán, dado que la obra fue muy leída entre los coetáneos, a pesar de su limitada difusión impresa ${ }^{9}$. Generalmente se asume que Torres Villarroel es un autor que continúa las formas del discurso heredado del Barroco ${ }^{10}$, y ello es cierto en gran medida. Pero no es menos verdad que el Piscator es un hombre de su época capaz de fusionar el caudal heredado con las preocupaciones definitorias de su tiempo. Esta vocación de sincretismo y su permeabilidad a los cambios epocales están presentes en buena parte de sus escritos, y la poesía no es una excepción.

Son muchas las particularidades de interés de los Juguetes de Talía, entretenimientos del numen, algunas de las cuales hemos tratado en un trabajo anterior $^{11}$. Entre otras, se puede destacar que el libro, por su disposición editorial, crea una interdiscursividad poemática entre las distintas piezas del poemario, lo que permite la lectura secuenciada del volumen como si de una vida poética en progreso se tratara, a lo largo de la cual se testimonia una suerte de «itinerario burgués» ${ }^{12}$ del escritor que se muestra en las composiciones mediante la particular imagen literaria que construye de sí mismo. Este recorrido se facilita mucho gracias a los paratextos de que se acompañan los poemas, los cuales sirven para reproducir la historicidad originaria que suscitó la escritura de los versos y también para orientar el sentido de cada pieza dentro del ensamblaje general del libro. De ese modo, los paratextos restituyen el aquí y ahora de cada poema, ofreciendo al lector el contexto pretérito de la escritura originaria y actualizándolo inalterablemente en el volumen salido de la imprenta.

El poemario se divide en tres grandes bloques de composiciones: sonetos, poemas varios (mayoritariamente octosilábicos) y un poema épico en octavas sobre la conquista de Nápoles. De modo más concreto, y atendiendo al criterio estrófico-temático que articula el libro, los Juguetes de Talía, entretenimientos

\footnotetext{
fenómeno que apareció en nuestros horizontes el día diecinueve de octubre de este año de mil setecientos y veinte y seis, Salamanca, Imprenta de la Santa Cruz, 1726 y Entierro del «Juicio Final» y vivificación de la Astrología, herida con tres llagas en lo natural, moral y político; y curada con tres parches. Parche primero: la Astrología es buena y cierta en lo natural. Parche segundo: La Astrología es verdadera y segura en lo moral. Parche tercero: la Astrología es útil y provechosa en lo político, Madrid, Imprenta de Antonio Marín, 1727.

9 Sebold defiende que la Poética de Luzán, a pesar de su limitada difusión editorial, ejerció una notabilísima influencia en el mundo intelectual del xvII por medio de fuentes secundarias, pese a su limitada difusión editorial (LuZÁn, Poética, págs. 55-64).

$10 \quad$ Véase nota 2.

11 Ignacio García Aguilar, «Los Entretenimientos del numen (1738) de Torres Villarroel: antología poética y vida literaria», Bulletin Hispanique 115.1 (2013), págs. 97-123.

12 Sobre este característica y su influencia en el poemario llamó la atención Maria Grazia Profeti, «I Juguetes de Thalia, di Torres Villarroel: un itinerario "borghese"», en AA. VV., I Secoli d'Oro e i lumi. Processi di risematizzacione, Florencia, Alinea Editrice, 1998, págs. 9-22. Una interpretación similar, aplicada de manera general a la obra torresiana, la planteó Juan MARICHAL, «Torres Villarroel: autobiografía burguesa al hispánico modo», Papeles de Son Armadans, 36 (1965), págs. 297-306.
} 
del numen se organizan del siguiente modo: sonetos morales (págs. 1-32), sonetos amorosos (págs. 32-73), tres silvas y una octava, dirigidas a Filis (págs. 7479), romances (págs. 80-168), décimas (págs. 168-172), liras (págs. 173-190), seguidillas (págs. 190-199), redondillas (págs. 200-219), quintillas (págs. 220233), glosas (págs. 234-243), coplas «de repente» (págs. 244-248) y, por último, las octavas de la Conquista del reino de Nápoles (p. 249-301).

El volumen, por tanto, se inicia con una sección de varios sonetos que se presentan bajo el rótulo de «morales» (págs. 1-32) y que proceden, en su mayoría, de una recopilación publicada doce años antes: los Ocios políticos $(1726)^{13}$. Los poemas que componen esta primera sección de carácter moral desarrollan, en clave mayoritariamente satírica, asuntos relacionados con la vida cortesana, universitaria, la crítica a los médicos o las vivencias reales del poeta con personas de su entorno, como el marqués de Flores Dávila, o su participación en diversos eventos de carácter festivo. A estos 59 primeros sonetos de tono moral (entendida la moralidad en un sentido muy particular o torresiano) siguen otras 82 composiciones tituladas como Sonetos amorosos, que serán el objeto de nuestro interés en el presente trabajo.

Este segundo bloque de sonetos amorosos aparece inicialmente dirigido a una dama denominada Filis. La elección de semejante molde estrófico y de una dedicataria poética con ese nombre podría invitar a pensar en un seguimiento del modelo quevedesco o de una agrupación aurisecular próxima al canzoniere petrarquista o similares modos dispositivos propios del Barroco, por lo que atañe a la selección genérico-estrófica y temática ${ }^{14}$. Sin embargo, se percibe muy pronto que Torres Villarroel no se somete servilmente a un modelo tan conocido y tan superado a estas alturas del Bajo Barroco ${ }^{15}$. Así se constata con la clara relativización de algunas de las coordenadas que definían lo amoroso en la centuria anterior, como la paradigmática amada única. Frente a este axioma de la lírica amorosa, se observa que en los sucesivos poemas de la sección torresiana las apelaciones a la inicial Filis se van ampliando para dar cabida a muchas otras referencias a mujeres, acabando de ese modo con una de las características definitorias de las agrupaciones poemáticas de carácter amoroso:

13 Diego de Torres Villarroel, Ocios políticos, Madrid, Isidro López del Hoyo, 1726. Para un acercamiento a esta obra véase Irene VALLeJo GonZÁLEZ, «Consideraciones sobre Ocios políticos, primer libro de poesías de Torres Villarroel», Edad de Oro, 31 (2012), págs. 11-37.

14 Para las prácticas editoriales en la poesía aurisecular véase Ignacio García Aguilar, Poesía y edición en el Siglo de Oro, Madrid, Calambur, 2009.

15 Para el alcance de la noción de «Bajo Barroco» véase Pedro Ruız Pérez, «Para la historia y la crítica de un período oscuro: la poesía del Bajo Barroco», Calíope. Journal of the Society for Renaissance and Baroque Hispanic Poetry, 18.1 (2012), págs. 9-25, así como «Periferias: la poesía del Bajo Barroco y el canon», Versants, 60.3 (2013), págs. 11-25. 
la univocidad de la amada. Por otro lado, y aunque la selección de las composiciones y su homogeneidad en el género-estrofa que es el soneto evocan recopilaciones muy codificadas en la tradición literaria previa, desde el propio inicio de la sección comienzan a desplegrase sentidos que apartan la construcción discursiva de muchos de los patrones de antaño, con el importante componente de desacralización y reescritura paródica que ello comporta. No en balde, Torres Villarroel abre sus Sonetos amorosos, justamente, con un poema en el que Explica el poco miedo que tiene al amor y el sumo poder de los ojos de Filis. Toda una declaración de intenciones:

Ente chismoso, fábula, quimera, diosecillo infernal, diablo cojuelo, ¿yo por ti ni un suspiro ni un desvelo? ¡El diablo me llevara si tal diera!, si Filis, con sus ojos, no viniera guardándote mi rabia, picaruelo, cuando tu arpón o tu carcax o anzuelo de haberme herido blasonar pudiera.

Si quieres ver al libre ceño mío burlar el fuerte impulso de sus botes, sin Filis ven conmigo a desafío, que, sin más que mirarme los bigotes, arañado saldrás de mi albedrío y te daré muchísimos azotes ${ }^{16}$.

En el soneto se pone en duda el poder del dios del amor, quien se salva de recibir golpes, momentánemante, por venir acompañado de una mujer. Además, se le rebaja a la mayor materialidad humana y se le amenaza con una paliza, invirtiendo así desde el inicio un patrón sólidamente establecido sobre su fuerza invencible y su capacidad para intervenir en el libre albedrío del enamorado. Parecería como si desde el comienzo de los Sonetos amorosos existiera la intención de apartarse de muchos de los tópicos y clichés establecidos, como el Omnia vincit amor, et nos cedamus amori.

A lo largo de las páginas siguientes se encarece a Filis en un equilibrio entre el seguimiento de la retórica tradicional y la apertura a nuevos horizontes. Se

16 Torres Villarroel, Juguetes de Talía, entretenimientos del numen, Salamanca, Imprenta de Santa Cruz, por Antonio Villarroel, 1738, pág. 32. Todas las referencias responden a esta edición en la página indicada. 
empieza a vislumbrar así una inversión paródica en cuya reescritura se pueden comenzar a atisbar los perfiles de un cambio, el cual se basa en el conocimiento de los patrones heredados y en la conciencia de su ineficacia para el momento actual. El claro diálogo que se establece entonces con la tradición previa pone al descubierto la convencionalidad de una retórica codificada. El proceso es progresivo, pero algunas de sus peculiares particularidades se entrevén desde el comienzo mismo, pues si el primer soneto se dirigía, sin ambages, a una Filis prototípica y reconocible entre los lectores de poesía, ya en el tercer y cuarto poema de los Sonetos amorosos comienzan a entreverse la artificiosidad retórica de todo el artefacto dispositivo. Conforme a ello, en la tercerca composición el paratexto del título indica que Encarece a Filis sus afectos (pág. 34); en tanto que en el siguiente se deja claro que el resultado literario es fruto de un ejercicio de reescritura de la tradición anterior, como denuncia su título: Encarece a Filis sus afectos con imitación del Camoes (pág. 34).

Aunque el motivo (amoroso) y la destinataria femenina (Filis) no cambian, la referencia al poeta portugués pone de manifiesto el carácter actualizador de la escritura poética torresiana. Aporta, además, otro elemento que marca una distancia con los modelos anteriores de sonetos amorosos: la sustitución de la confesionalidad enunciativa por la revelación de la naturaleza no vivencial del yo lírico, lo que ocurre también en el siguiente soneto, escrito por El pastor Fabio a su adorada Filis (pág. 34). En estos versos, la referencia a lo bucólico y al Fabio prototípico de la escritura moral en el Siglo de Oro ${ }^{17}$ delimita los perfiles de un dibujo lindante con lo idealista, pero que subraya, fundamentalmente, la dimensión ficcional y artificiosa de lo escrito, así como la ruptura entre la voz poemática y el sujeto histórico que escribe los versos. Esta característica definitoria se continúa en los poemas inmediatamente posteriores, en los que se canta la hermosura del cuerpo de la amada Filis, su perfección espiritual, su honestidad y constancia en el amor, sus lágimas, sus ojos o su belleza (págs. 37-45).

La naturaleza literaria y, por ende, ficcional de los poemas requiere de un referente poético femenino para la efectiva articulación retórica del discurso lírico amoroso. Por lo tanto, es la convención la que justifica y determina tanto la inclusión de Filis como el tratamiento (no exento de parodia) que se le concede, lo cual enuncia y evidencia con diáfana claridad Torres Villarroel en el soneto A Filis, encareciendo su adoración:

17 Isabel Colón Calderón, «El linaje de Fabio», eHumanista: Journal of Iberian Studies, 3 (2003), págs. 91-104. 
Góngora, Lope y otros, que la idea de las musas fingieron altamente, por objeto del numen elocuente tuvieron su deidad, su Dorotea.

Yo, Filis, discretísima Medea, hechizo universal de lo viviente, en tu belleza tengo reverente mi ejercicio, mi gloria y mi tarea.

Ellos, con el donaire y la dulzura del plectro que al espíritu se exalta, de su atención lograron la ventura.

Mi musa no es tan grave ni tan alta, mas, para merecer a tu hermosura, me suple amor lo que al ingenio falta (pág. 41).

Además del carácter convencional y retórico de los versos, en el poema también se pone de manifiesto la contraposición entre dos tiempos y dos generaciones literarias distintas; en otras palabras, se evidencia la conflictiva tensión entre el «ayer»y el «hoy», el «ellos»y el «nosotros», lo que supone, de acuerdo con Pérez Magallón, una dialéctica específica y definitoria del nuevo modo de pensar que había surgido con los novatores ${ }^{18}$. De acuerdo con esto, el primer cuarteto corresponde con claridad al pasado, a lo que se contrapone el presente del «hoy»y del «yo» con que se inicia el segundo cuarteto. Así pues, desde el tiempo de la enunciación se evidencia la clara conciencia de que el canon amoroso de los Góngora, Lope y Quevedo, sea cual fuere, no es el que se actualiza en el presente de la escritura, lo cual no solo implica un conocimiento del repertorio previo, sino también, y esto es más importante para el caso que nos interesa, una afirmación de la diferencia y una implícita voluntad de separarse del modelo codificado por la tradición precedente.

El soneto, bien ilustrativo de la oposición referida, sirve también como botón de muestra de lo que acontece en el conjunto de la sección amorosa, pues la evolución cronológica que se sugiere en los catorce endecasílabos a los que acabamos de referirnos tiene su correlato macrotextual en la manera en la que se organizan los sonetos en esta sección de los Juguetes, cuya lectura permite comenzar revisando el pasado (o ayer) del tópico amoroso (con los cambios ya señalados) en proyección hacia un presente definido por versos más atentos a la

18 Jesús Pérez Magallón, Construyendo la modernidad: la cultura española en el tiempo de los novatores (1765-1725), Madrid, CSIC, 2002, pág. 17. 
circunstancia extratextual (señalada en los encabezados) que a la intertextual o puramente literaria. De acuerdo con esto, los Sonetos amorosos de Torres Villarroel se podrían dividir en dos partes claramente diferenciadas. Una primera, correspondiente a la veintena de composiciones iniciales, todas ellas dedicadas a Filis, con que se abre la sección; y una segunda en la que se englobarían los 62 sonetos posteriores, en los que Filis desaparece y deja paso a mujeres históricas de carne y hueso.

Así pues, los primeros veinte sonetos se dirigen en exclusividad a una Filis que es prototipo de la retórica y valores de antaño, a la que es necesario decir adiós para poder proseguir por un nuevo camino. Y así se hace desde el decimoctavo soneto de la serie, titulado, precisamente, Despídese de Filis, cuyo primer cuarteto habla muy a las claras de los necesarios vientos de renovación y cambio:

Adiós, Filis, adiós, dueño adorado, quédate en paz, pues quiere mi lamento que lleve mis suspiros otro viento, que de tu esfera hermosa está apartado (pág. 43).

La despedida se prosigue en los dos siguientes poemas, en el último de los cuales, el vigésimo, se incide en la idea de cierre sin solución. Se trataría, en todo caso, de un agotamiento literario, que tiene que ver con la caducidad del repertorio canónico y de los modos poéticos anteriores:

Aún más allá del fin he de adorarte, que es eterno el influjo de quererte.

No hay que apelar, como otros, a la muerte, pues hasta mis cenizas han de amarte (pág. 44).

Lo llamativo del caso, más allá de la referencia al quevediano «polvo enamorado", es que aquí el acabamiento no tiene que ver con la vida y la muerte físicas, sino con la escritura y con los referentes a los que se decide erigir en protagonistas poéticos de los versos. Por tanto, el abandono de Filis proviene de una decisión voluntaria de quien enuncia su amor sufriente y, como resultado, puede escribir su dolor. Pero el dolor por la distancia y la pérdida no es fruto de los azares del destino, que ataja la vida de uno de los enamorados; sino que es resultado de un plan diseñado para ampliar las limitadas posibilidades de un conflicto amoroso único y exclusivo, cuyas riendas lleva el yo poético. La promesa formulada en el vigésimo de los Sonetos amorosos, así como el voluntario 
abandono de Filis, contrasta de modo muy llamativo con el siguiente poema, que es el que inicia la segunda parte. La inflexión se puede intuir desde el título: Dice a una dama la pureza de su adoración. La indeterminación («una») de la destinataria referida y el claro destierro de la Filis adorada en las dos decenas de composiciones previas prefiguran una clara inflexión, pero lo que verdaderamente marca un antes y un después es la muy distinta «adoración» a la que se alude, claramente perceptible en el primer cuarteto del poema:

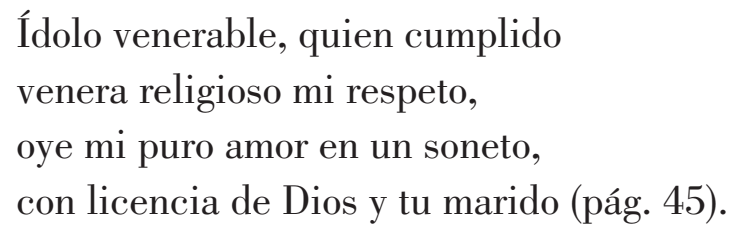

Las alusiones a la mujer como ídolo y a una suerte de religio amoris pueden ser reminiscencia paródica de escritos anteriores, pero no implican, en modo alguno, seguimiento de los modelos de sentimentalidad barroca, pues lo que de verdad tiene relevancia, a nuestro juicio, es la clara manifestación de convencionalidad y naturaleza social de lo poético amoroso. Una vez que se destierra a la Filis prototípica del pasado, la amada es textualización de la circunstancialidad del hoy. Ello se aprecia, en primer lugar, en el explícito vínculo genéricotemático que se expresa desde el poema en la imprecación del tercer verso; pero de modo mucho más nítido y contundente, en el necesario consentimiento del marido para que su esposa sea poéticamente cortejada, en clara alusión a la práctica del chichisveo, tan criticada por el autor en alguno de sus Sonetos morales $^{19}$. Que Torres Villarroel embista contra el chichisveo en una parte de su libro y lo utilice como elemento fundamental en otra sección distinta podría resultar contradictorio o, al menos, paradójico. Ello se explica por el hecho de que en un caso lo hace dentro del grupo de poemas morales y en otro forma parte de una selección y recopilación de composiciones amorosas, adecuadas todas ellas a las claves que marcan el funcionamiento de la sentimentalidad dieciochesca: un tiempo nuevo en el que el amor secreto y clandestino de antaño se había convertido en pública exhibición de galanteo ${ }^{20}$.

19 Así ocurre, por ejemplo, en el soneto en que Habla con don Francisco de Quevedo en las sátiras a los cornudos, cuyos tercetos no dejan en muy buen lugar a quienes practican el chichisveo: «Para cuatro cornudos vergonzantes, / que usted alcanzó en su siglo ya perdido, / hizo extremos y sátiras picantes. / Dé mil gracias a Dios no ser nacido, / pues si hubiera alcanzado chichisvantes / antes fuera cornudo que marido» (TorRES Villarroel, Juguetes, pág. 12).

20 Para la elucidación y el sentido de estas prácticas sociales véase el estudio de Carmen MaRTín GaITE, Usos amorosos del dieciocho en España, Madrid, Siglo XXI, 1972. 
La ruptura con respecto al modelo poético más conocido se percibe diáfana a medida que se recorre la sección de Sonetos amorosos. Además de en los versos apuntados, se puede constatar la superación del paradigma en otras composiciones, como por ejemplo la titulada Mándale Filis hacer un soneto bueno y responde la dificultad que siente en tales composiciones:

No puede ser mandato, será enredo de tu chanza burlona y peregrina.

¿Piensas que puedo hacer, Filis divina, milagros como tú? Pues no, no puedo.

¿Yo buen soneto? Búscalo en Quevedo (pág. 46).

Se apela a Quevedo por lo que implica de modelo expresivo que encarna la voluntad de sublimación del yo a través de la escritura lírica de poemas amorosos. Pero además, la referencia sirve al propósito de comparación y distanciamiento que permite medir las diferencias entre una y otra propuesta, las cuales son orgullosamente reivindicadas por Torres Villarroel, quien no rechaza de lleno las imágenes y las formas heredadas, aunque las actualiza dotándolas de nuevos sentidos acordes a las complejidades de su tiempo. El desplazamiento semántico desde modelos y formas conocidos, al que nos hemos referido en las páginas previas, alcanza incluso a la construcción de la que es la estrofa más característica de todo este edificio literario e ideológico: el soneto.

En un trabajo fundamental, colmado de vigencia y validez, Juan Manuel Rozas explicó la función semántica de la rima aplicándola a un período concreto: el petrarquismo español ${ }^{21}$. De su análisis se comprueba, en primer lugar, la recurrencia a la rima -ento en este tipo de poesía. En segundo lugar, de la reiterada utilización de este tipo de rima se desprende que existen sólidos vínculos entre la manera en la que se construye un determinado modelo genéricoestrófico, como es el soneto, y los vínculos de este con el pensamiento poético de una determinada escuela, caso del petrarquismo. Así pues, y partiendo del análisis de la rima en —ento, la más distintiva de la estética petrarquista, se puede recorrer la poesía aurisecular con resultados muy esclarecedores y de gran aplicabilidad a otros períodos histórico-literarios. Así, por ejemplo, comprueba Rozas que de los 93 sonetos del segundo libro de Boscán, hasta 33 se construyen con esta rima. $\mathrm{Y}$ de este tercio, un total de 17 repiten el término

${ }^{21}$ Juan Manuel Rozas, «Petrarquismo y rima en -ento», en Alberto Porqueras Mayo y Carlos Rojas, Filología y crítica hispánica. Homenaje al profesor Federico Sánchez Escribano, Madrid, Ediciones Alcalá, 1969, págs. 67-85. 
«pensamiento» (con el sentido de 'amor'), el cual se acompaña muy frecuentemente de la voz «tormento», «sentimiento»y «contento» o «contentamiento». Enlazando la secuencia se obtendría una definición bastante aproximada del fenómeno literario: el «pensamiento» (es decir, el 'amor') genera un «tormento» que, por lo que supone de elevación y trascendencia, produce «contento» o «contentamiento». Muy análogos resultados se obtienen cuando se aplica el mismo método tanto a otros autores coetáneos como a continuadores e imitadores posteriores de la estela petrarquista.

La metodología de análisis, por tanto, resulta aplicable a otros autores y períodos, y es lo que hemos hecho con Torres Villarroel. Así pues, y tomando como referencia la rima en - ento, tan definitoria y distintitiva de la sentimentalidad petrarquista, se comprueba que de los 82 Sonetos amorosos, 11 se construyen con este patrón de rima, lo que supone un nada desdeñable 12,5\%. El dato cuantitativo resulta de interés, pero mucho más el análisis cualitativo de los resultados, pues el desplazamiento desde lo idealizado y trascendente hacia lo racional, concreto y positivo tiene también su paralelo en la arquitectura de este molde genérico-estrófico.

En tres de los sonetos, en los cuales hay una cierta parodia revisitadora del petrarquismo más convencional, las composiciones se construyen con las rimas «entendimiento», «pensamiento»y «contento» (pág. 37); «siento»-«contento», «sentimiento»-«tormento» (pág. 40); y «contento»-«sufrimiento»-«tormento» (pág. 63). En otros poemas se continúa apelando a la idea del «tormento»y el «sufrimiento», pero vistos ya como elementos que deben desecharse para alcanzar nuevos horizontes, de manera que en el soneto titulado Despídese de Filis los pares «lamento»-«viento» apelan muy claramente al cambio aludido: «Adiós, Filis, adiós, dueño dorado / quédate en paz, pues quiere mi lamento / que lleve mis suspiros otro viento» (pág. 43). Y la muy similar dupla «viento»«acento» reaparece en el poema dirigido A toda la tropa de poetas burdos y en elogio de Francisca Vallejo, de la parte final de la sección (pág. 72). También nuevos aires, pero desde la dramatización poética, se atisban en el «violento»«nacimiento» evocado en la composición que lleva por título: Habiéndole pedido a una dama un traje que tenía de serrana para una pastora de un Nacimiento que hizo en su casa de doña Josefa de Torres, hermana del autor, le escribió a esta dama, dándole cuenta de todo, este soneto (pág. 56).

Pero lo que resulta más interesante de este repaso por las rimas de los sonetos torresianos es la clara inflexión hacia referencias conceptuales que tienen que ver con la razón y la inteligencia, apreciables en aquellas composiciones, como el soneto séptimo de la serie, en que se alude a «rendimiento», «portento» y «entendimiento» (pág. 35); o el poema décimo, en que se concilian el 
«talento»y el «conocimiento» (pág. 37). También sobre las nociones del «pensamiento» y el «talento» se construyen los sonetos A lo que él [el amor] expresa (pág. 52) y el que Dice a Filis lo imposible de copiar su hermosura (pág. 37). Análogamente, el «pensamiento», en tanto que agente con potestad para elegir individualmente las pasiones, ocupa un lugar de gran relevancia en el soneto que Pondera su amor y el motivo que le mueve a no querer (pág. 53). «Entendimiento» y «pensamiento» son utilizados hasta en la última composición con la que se cierran los Sonetos amorosos, cuando se Dice a Filis lo imposible de copiar su hermosura en este Soneto (pág. 73).

Un cambio como este, que apunta hacia una mayor preponderancia de lo (entendido como) racional frente a la idealizada naturaleza de la protagonista femenina de la tradición previa, se aprecia con claridad, además de en algunos de los versos aducidos, en un poema como el titulado Pide a una dama su mano para decir la buena ventura:

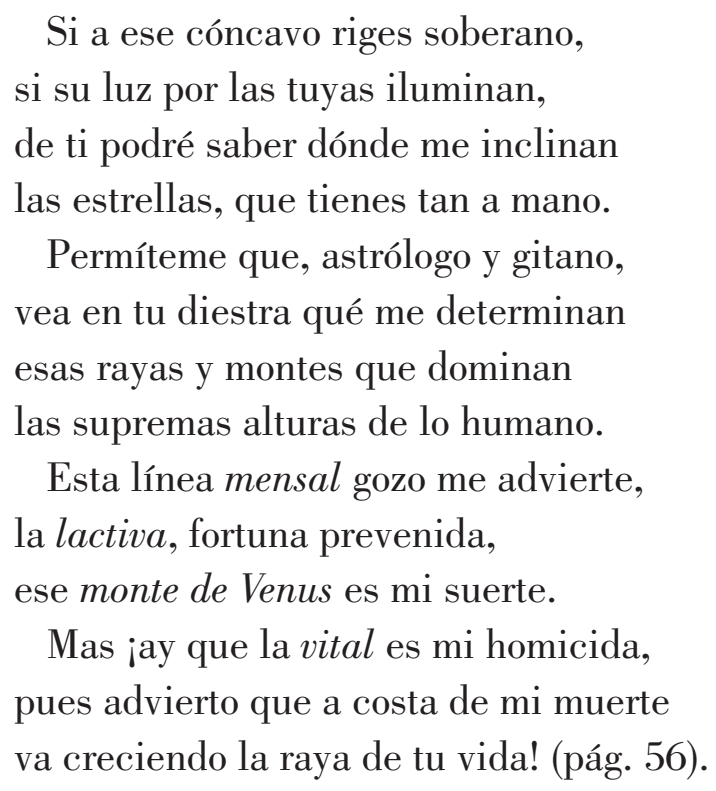

En el soneto la amada se hace carne y las peculiaridades de su materialidad (real y simbólica a un tiempo) propician las lecturas astrológicas de quien se expresa a través de los endecasílabos. La mujer no es ya el objeto idealizado e intangible (o intocable) de la escritura sino, fundamentalmente, un sujeto histórico palpable que es signo, en sí mismo, de una nueva razón articulada, en este caso, mediante la semiótica astrológica («mensal», «lactiva», «monte de Venus», «vital»). Todo ello permite, por parte del sujeto poético masculino, una lectura utilitaria en sentido profesional e incluso crematístico, si se atiende a los pingües beneficios que el propio Villarroel obtuvo de su manejo de la astrología. 
En esta misma línea de materialización de lo antaño ideal y de manifiesta presencia de una mujer histórica que se desenvuelve en situaciones ordinarias, merece destacarse el soneto que sigue al que se acaba de mencionar (Pide a una dama su mano para decir la buena ventura):

Habiéndole pedido a una dama un traje que tenía de serrana para una pastora de un nacimiento, que hizo en su casa de doña Josefa de Torres, hermana del autor, le escribió a esta dama dándole cuenta de todo en este soneto

Cesó de los ensayos lo violento, empezó con la fiesta la alegría, el acto sin desgracia proseguía, con que salió de madre el Nacimiento.

Don Juan hizo a Luzbel, con ardimiento; José, a San José; Frasca, a María; mi hermana, una pastora que vestía tu condición, tu traje y tu tormento.

Yo hice un pastor amante y no creído, quizá porque, con traje de serrana, lo falso le pegó y lo fementido.

Pues, ¿qué espero de ti, dulce tirana, cuando el contacto solo del vestido vuelve en desprecios el amor de hermana? (pág. 56).

Resulta obvio que un poema como este debió de componerse para funcionar en un entorno minoritario de sujetos que conocían los códigos dramáticos a los que se alude. Esa información se reproduce en el paratexto para ofrecer al desconocido lector del libro unas mínimas orientaciones sobre el contexto originario de escritura. Con estos datos se puede comprender que en un entorno de sociabilidad literaria en el que la poesía sirve como juego y distracción, lo amoroso no es sino una máscara al servicio de un desempeño que no tiene que ver con las prácticas del ambiente cortesano o académico, sino que es propio del salón dieciochesco y de una sentimentalidad vinculada a este espacio y a los modelos de sociabilidad que en él se despliegan.

La tematización amorosa y el soneto se alían en este caso para convertirse en vehículo de juegos dramáticos. El maridaje de poesía y teatro que se plasma en el poema es una antesala perfecta para las composiciones con que se cierra la sección de los Sonetos amorosos. Se trata de algo menos de una veintena de estrofas con los que el Piscator elogia y defiende a las «farsantes», al tiempo 
que arremete contra todos aquellos que las critican ${ }^{22}$. El principal argumento sobre el que edifica sus elogios reside en la amplia aceptación de estas actrices entre el público: «¿Cómo, siendo en el arte tan canijos, / de Antonia provocáis el sobrecejo, / cuando son sus aplausos tan prolijos» (pág. 68). La validación a través del mercado tiene su antecedente más claro en Lope, a quien Villarroel no desdeñaba, como se comprueba con la mención antes señalada o las que utiliza en algún verso de estos últimos sonetos de la serie: «Válgame Apolo, ¿qué dijera Lope / al escuchar tan disonante tropa» (pág. 69) o «¡Válgame Lope, ¡cuánto poetilla / cencerra! ¡Cuánto lírico muleto! / Tontos de afolio, que hacen un soneto / como habían de hacer una morcilla» (pág. 72).

Esta defensa de las profesionales del oficio dramático está en consonancia con los intereses que el propio Torres Villarroel tenía en que se valorase positivamente la profesionalización en el ámbito de la literatura de masas. El Piscator, sin embargo, no optó por el teatro como medio de promoción y obtención de dinero, sino fundamentalmente por los pronósticos. El encomio de estas actrices, por tanto, no es difícil de justificar en un caso como el del salmantino. Más difícil se antoja entender la opción por ubicar tales poemas, que habían sido estampados exentos con anterioridad, como broche final de sus Sonetos amorosos, pues no es fácil vislumbrar qué hay de amor en estas piezas dirigidas a cuatro cómicas distintas de su inmediata realidad histórica.

Desde luego, cabría asegurar que nada en absoluto si se tienen en cuenta los veinte sonetos iniciales consagrados a Filis; y mucho menos si se concibe el amor desde una perspectiva aurisecular, en tanto que itinerario de elevación, sublimación y perfeccionamiento. Tampoco encajan estas últimas composiciones en un diseño cancioneril, si es que se entiende que ese es el propósito del Piscator al seleccionar y organizar este conjunto de sonetos. Obviamente, los Sonetos amorosos del salmantino son algo muy distinto al análogo molde aurisecular, por más que entre sus versos se reproduzcan muchos dejes formales y se aluda a Lope, Góngora o Quevedo. Valga aducir al respecto que también el Diccionario de Autoridades consideraba la auctoritas de estos escritores para

22 El epígrafe que redacta el autor para esta serie de sonetos es tan extenso como clarificador del tipo de composiciones que le siguen: Geriganzo con su Catalinón y Girapliega, a los poetas duros y cacochimicos, que tienen obstinado el vientre de el celebro. Es un salpicón contra los que son impotentes de meollo y eunucos de fantasía para producir la agudeza: salvajes tolerados que están metidos de mogollón en la tropa de los discretos y viviendo de gorra en el coro de los legítimos hijos de las musas. Zahiérense con este jeringatorio las coplas con que están cagando las resmas y llenando los papeles de gargajos de consonantes en ofensa de las cómicas, alabándolas en estilo bruto con décimas de coz y bocado. Celébranse en este papel las bellezas, chistes, habilidades y gracias de las cuatro que no se comprehendieron en el antecedente. Es, a saber, María Antonia de Castro, Antonia Mejía, Francisca Vallejo y la Chaves. Y se les amonesta a los poetas pellejos que dispongan el nalgatorio para otro jeringazo con que se les salpicará de apodos en pasando la Cuaresma (TorRes Villarroel, Juguetes, pág. 64). 
sus definiciones, aunque no por ello se duda del carácter distintivo de modernidad y progreso de este empeño lexicográfico ilustrado. Atendiendo, pues, a esta voluntad de diálogo actualizador y superador de los modelos previos, había amor en los sonetos. Pero ocurre que no era el amor que vehiculaba la añeja sentimentalidad del XVII, marcada por la idealización y la trascendencia, sino un amor en sincronía con los intereses de su tiempo, preocupado de la realidad inmediata y sujeto a la comprobación de su materialidad tangible.

Un soneto de enfado y desengaño: sentimiento torresiano y razón ilustrada

El recorrido de las páginas previas por los Sonetos amorosos de Torres Villarroel ha sido, necesariamente, de carácter general y se ha orientado la atención hacia el análisis de los elementos que tienen mayor interés en la renovación del legado lírico de la tradición aurisecular. Por ello, nos detendremos ahora, de manera más pormenorizada, en un poema que puede resultar muy ilustrativo de lo que se ha expuesto en las páginas precedentes. Además, el soneto objeto de nuestra atención permite apreciar algunas de las más llamativas particularidades de la poética torresiana en lo que a sentimiento y razón se refiere. Se trata del soneto que aparece bajo el rótulo Escribe enfadado a una dama desde un retiro religioso:

Escondido, gustoso y retirado, yace en aquesta estancia religiosa mi corazón, que tímido reposa del tristísimo afán de su cuidado.

Gracias a Dios, ya está desengañado de aquella imagen falsa, cautelosa, que, con dulces sorbetes de amorosa, le dio a beber ponzoña en el agrado.

No volverá a pillarme, ingrato dueño, tu taimada e infame tiranía, no he de salir de aquí, que ya es empeño.

Logre usté a su placer lo que quería, haga usté cuenta que mi amor fue sueño y vaya usté a la mierda, reina mía (pág. 60).

Probablemente, los versos conclusivos son los que más llaman la atención, por el tosco tratamiento que se concede a la amada. Y tanto es así que en una 
edición moderna del poema se opta por modificar el último verso y colocar en su lugar el siguiente: «y tenga usted al despertar un nuevo día»"23. Sin entrar en otras consideraciones sobre la calidad del endecasílabo y la orientación semántica del conjunto, lo que prueba esta deturpación textual es que incluso para la sensibilidad y el canon contemporáneo la apelación a la malsonante excrecencia se antoja inadecuada. Ya lo advirtió Laporte cuando señalaba que «de la mierda no se habla. Pero ningún objeto, ni siquiera el sexo, ha dado tanto que hablar, y esto ha ocurrido siempre ${ }^{24} \gg$.

Desde antiguo, en la tradición literaria española, la mierda aparece en obras de burlas, fundamentalmente, y es muy frecuente en el modo de hablar de los personajes marginales y en su literatura específica. Así, se encuentran recurrencias en la Lozana andaluza y también, por ejemplo, en el Cancionero de Horozco, donde se localiza en dos composiciones: el caso de un boticario que se dedicaba a hacer mescolanzas indebidas, resultando finalmente que todo eran heces, y en un poema a Antonio de Ávalos sobre un conejo que se comieron y no limpiaron bien. Asimismo, en el Anónimo Sermón de Aljubarrota (c. 1545) se dice que los portugueses beben agua con mierda, como es costumbre, y posteriormente se afirma sin ambages que toda Portugal es aquello que beben sus habitantes. De igual modo se pueden ver composiciones con excrementos en los cuentos de Timoneda y otros relatos populares. En los Refranes (c. 1549) de Hernán Núñez se recoge el refrán: «Quien come peces menudos come mierda de muchos culos». Y se explica: «Porque los peçes menudos andan a la orilla del agua, donde las mugeres lavan sus trapos». Muchos otros hay en Gonzalo Correas (1627), como por ejemplo: «Al ke de miedo se muere, enterralle en mierda, i hazelle de kagaxones la huesa»; «Al ke de rruin se muere, de mierda le hazen la huesa» 0 «La kaka, peor es hurgalla. La mierda, dexalla estar keda». En CORDE no hemos podido encontrar ninguna otra referencia a este término desde 1627, que aparece en Correas, hasta 1727, en que se recoge en las Visiones y visitas de Torres con Don Francisco de Quevedo por la corte, de Torres Villarroel. Ello no significa que no esté presente el término en otros textos, pero tal ausencia es llamativa en una base de datos como esta, e igual de llamativo nos parece la posterior reaparición en el texto torresiano, con un significado distinto del que tenía en la literatura previa a la que nos acabamos de referir.

Por otro lado, que la mención a lo fecal aparezca en 1727 dentro de un libro con tan claros vínculos, desde su título, con Francisco de Quevedo podría ser

23 Diego de Torres Villarroel, Sonetos, ed. Ramón García González, Alicante, Biblioteca Virtual Miguel de Cervantes, 2006, pág. 61. http://www.cervantesvirtual.com/obra/sonetos--8/.

24 Dominique Laporte, Historia de la mierda, Valencia, Pre-Textos, 1998 [1. ed., Valencia, 1980], p. 113. 
una pista para entender su sentido; pues sin duda alguna, el gran cantor de lo escatológico en el Siglo de Oro es el autor madrileño, quien se vale de este elemento, las más de las veces, con una intención burlesca o de sátira furibunda. Así las cosas, podría solventarse la interpretación del soneto torresiano aduciendo que se trata de un poema que sigue muy de cerca los modos de Quevedo, a quien tan aficionado era Villarroel y a quien tanto deben algunas de las obras del Piscator.

Como resulta bien conocido, no son pocos los textos en los que Francisco de Quevedo se vale de lo escatológico para la construcción de su discurso. De modo más específico, la mierda aparece explícitamente en algunos de sus versos, como por ejemplo en las coplas que escribe el madrileño para contestar unas décimas gongorinas: « ¿cuál hombre o mujer que canta, / si tiene cabeza cuerda, / a pies de coplas de mierda, / hará pasos de garganta?» ${ }^{25}$. También en uno de los sonetos que dirige contra Góngora califica al cordobés como «doctor en mierda, gradüado en pujos» (pág. 1178); y en un Epitafio al mesmo explica del autor de las Soledades «que nunca, que yo sepa, / se le cayó la mierda de la boca» (pág. 1179). Se pueden encontrar imágenes excrementicias, asimismo, en otros textos de Quevedo cargados de crítica acerada no solo contra poetas rivales, sino contra figuras y comportamientos que le desagradaban. Tal es el caso del Epitafio a un bujarrón, cuyos versos conclusivos resultan suficientemente ilustrativos de su postura crítica: «Pero si honrar pretendes su memoria, / di que goce de mierda y no de gloria; / y pues tanta lisonja se le hace, / di: Requiescat in culo, mas no in pace» (pág. 652). Y hay asimismo rasgos escatológicos en otros muchos lugares de la obra quevedesca, relacionados generalmente con la sátira y la burla, como en el Buscón o los Sueños ${ }^{26}$. Ejemplos de poemas en los que se busca la risa fácil serían los del miedo de los infantes de Carrión, claramente visible por las deposiciones en sus pantalones: «pues tan presto bajó el miedo / los yantares a las ancas» (pág. 1031), o el llanto de Hero por Leandro, que se acompaña de otras excrecencias.

Pero la mierda también aparece en Quevedo como elemento que, por su materialidad, corporeidad y realidad, sirve para manifestar evidencias y verdades. Así ocurre, por ejemplo, en el soneto sobre las cuatro edades del hombre, en donde el primer verso asocia el nacimiento a la suciedad que irremediablemente acompaña al individuo a lo largo de la existencia: «La vida empieza en

25 Francisco de Quevedo, Poesía original completa, ed. José Manuel Blecua, Barcelona, Planeta, 1981, págs. 1162-1163. Todas las referencias responden a esta edición, en la página citada.

26 Sobre esto véase Marie Roig Miranda, «Escatología y filosofía en Quevedo», Criticón, 99 (2007), págs. 57-66. Ya hace tiempo que Goytisolo hizo hincapié en lo que Maria Grazia Profeti ha definido como «La obsesión anal en la poesía de Quevedo». 
lágrimas y caca [...] / llega la muerte, y todo lo bazuca, / y lo que deja paga, y lo que peca» (pág. 561). Este poema, de inicio tan malsonante, plantea algo no muy diferente de lo expuesto en su soneto metafísico «Señor don Juan, pues con la fiebre apenas / se calienta la sangre desmayada, / y por la mucha edad, desabrigada, / tiembla, no pulsa, entre la arteria y venas» (pág. 3). Si bien es cierto que este segundo presenta una formalización textual y léxica muy distinta del primero.

Aunque las imágenes de los excrementos son utilizadas por Quevedo en muchos de sus textos con una finalidad satírico-burlesca, es posible encontrar también composiciones en las que dichas imágenes adoptan un significado distinto y se prestan a interpretaciones de mayor calado. En este sentido, se podría destacar un poema, incluido por Blecua en el grupo de los «poemas satíricos», en el que se describe y destapa la verdadera naturaleza imperfecta de la mujer real, en contraposición a la idealizada imagen femenina de la poesía petrarquista:

Que tiene ojo de culo es evidente, y manojo de llaves, tu sol rojo, y que tiene por niña en aquel ojo atezado mojón duro y caliente.

Tendrá legañas necesariamente la pestaña erizada como abrojo, y guiñará, con lo amarillo y flojo, todas las veces que a pujar se siente.

¿Tendrá mejor metal de voz su pedo que el de la mal vestida mallorquina? Ni lo quiero probar ni lo concedo.

Su mierda es mierda, y su orina, orina; solo que esta es verdad, y esotra, enredo, y estánme encareciendo la letrina (pág. 612).

El soneto pone al descubierto las inconsistencias de las descripciones esclerosadas, prototípicas y heredadas del modelo poético petrarquista mediante la confrontación con la realidad más objetivable, palpable y perceptible (hasta por el olor). En otros de sus versos, el escritor madrileño describe la tez de la amada como un campo de estiércol: «Tu mayo es bote, ungüentos chorreando / y en esa tez, que brota primaveras, / al sol estás y al cielo estercolando» (pág. 575).

Resulta evidente, tanto en uno como en otro poema, la desacralización del referente femenino y la superación del modelo, con la mierda de por medio. 
Desde esta perspectiva, podría entenderse que el poema de Torres Villarroel no plantea una ruptura abrupta con la tradición anterior, al menos con la que le resultaba más cercana desde el punto de vista cronológico y conceptual: el modelo de Quevedo. Se podría asumir, por ello, que el soneto torresiano prolonga una de las líneas compositivas del escritor madrileño y que extiende hasta el XVIII lo que ya era asumido por algunos de los grandes autores del XVII: que la sentimentalidad petrarquista tenía un difícil encaje literario en el mundo cambiante del Barroco.

Sin embargo, conviene advertir que existen algunas diferencias de importancia entre el tratamiento quevedesco y el torresiano. El de la Torre de Juan Abad, como se ha visto, se vale de las imágenes excrementicias para la burla ácida o la crítica, ya sea a figuras históricas, modos genéricos de comportamiento humano o modelos literarios caducos. En el caso de Torres Villarroel, la excrecencia es el lugar al que se manda a la amada. De inicio, ello supondría una mayor ruptura y un más acentuado distanciamiento con respecto al paradigma previo. Quevedo critica y parodia mediante la reescritura burlesca de los tópicos asumidos, desnudando así la arquitectura compositiva y dejando al descubierto las flaquezas e inconsistencias del modelo, junto con los lugares comunes que lo soportan. Sin embargo, la mujer, con todos sus problemas y debilidades, permanece textualizada en el poema, de uno u otro modo y con una u otra función. Pero Quevedo no se preocupa por ofrecer una alternativa sólida a ese paradigma de sentimentalidad lírica. Acaso porque no era este un asunto que desvelara al madrileño.

En el caso de Torres Villarroel percibimos elementos y detalles del soneto que permiten sugerir una diferente manera de encarar el problema. De inicio, la distinta o más amplia concepción que tiene el Piscator de la referencia al excremento, como se puede colegir de las recurrencias y sentidos con que la menciona en otros de sus textos. Más allá de lo burlesco y la crítica, aparece con un significado relacionado con lo mercantil en un pasaje significativo de, justamente, las Visiones y visitas de Torres con Don Francisco de Quevedo:

Ya esta alhaja nunca se vuelve a rescatar por el mismo dinero; pues aunque no viva más que media hora en el carcelaje, el dueño ha de pagar los cuatro pesos y más un real de plata de aumento en cada real de a ocho, y para las ánimas dos cuartos. Conque por entrar y salir la alhaja en la prisión del maldito paga cuatro pesos, cuatro reales de plata y ocho cuartos. Y si la prenda se detiene dos o tres meses, por cada mes se le aumenta a cada peso otro real de plata y otros dos cuartos; conque a pocos días se queda en la cautividad del usurero, sin arbitrio del rescate. Tienen estos hombres y algunas mujeres trato oculto de tabaco y otras especies, de 
modo que compran del estanco real o de algún fraude tres o cuatro libras de tabaco, añaden de mierda de cristianos o de cabras porción hasta hacerlas seis; éstas las rebujan y reparten en papelillos, que prestan y venden a la vecindad, y doblan dos veces el dinero en cada libra, y dedican su ambición a otras indignidades odiosas de contar ${ }^{27}$.

Podría señalarse la coincidencia de aludir a estos residuos del organismo para hablar de la realidad del mundo, como ya había hecho Quevedo en alguno de los poemas citado. Pero es que además, en el texto del salmantino, se trata de un panorama gobernado por el negocio y el afán de lucro, lo que lleva al falseamiento de la naturaleza de las cosas que se ofrecen y pregonan. Tratándose además, como es el caso, de un autor netamente profesional y perfectamente imbuido en las prácticas del negocio editorial, los contornos semánticos de la mierda recomiendan ampliar las posibilidades significativas y extender el potencial de su referencialidad. No en balde, continuando con la lectura de esta obra en la que tan claramente se apela a Quevedo, nos encontramos de nuevo con una alusión a los excrementos. En este caso su razón de ser tiene que ver con la descripción de la materialidad de un espacio doméstico, no debidamente acondicionado, de modo que «en otro rincón se descubrían muchos montones de mierda de todas castas, aquí un manojo de hierbas, allí un revoltillo de pelos, ollas con leche, orines y sangre ${ }^{28}$.

Si revisando los distintas apariciones y usos de la mierda en Quevedo se concluye que esta tiene sentidos que van desde lo satírico-burlesco hasta casi lo existencial, también en Torres Villarroel se puede construir, mediante el recorrido por su obra, el lugar que ocupa en su imaginario poético la imagen de la excrecencia; o a lo menos es factible presentar hipótesis fundamentadas en la reiteración y el contexto con que se menciona lo fecal en los escritos torresianos. Conforme a esto, y de acuerdo con los textos aducidos, pensamos que es posible ubicar las referencias a los excrementos en Torres Villarroel dentro de una parcela que tiene que ver con el comercio y los negocios domésticos, aunque no son estos los únicos sentidos asociados a las excrecencias.

En 1724, dos años antes de que Feijoo alumbre el primer tomo de su Teatro crítico, publica Villarroel el Viaje fantástico, cuya ampliación dará lugar catorce años más tarde a la citada Anatomía de todo lo visible e invisible. En la obra, Torres Villarroel se sirve del marco onírico para plantear una síntesis divulgadora

27 Diego de Torres Villarroel, Visiones y visitas de Torres con Don Francisco de Quevedo por la corte, ed. Russell P. Sebold, Madrid, Espasa-Calpe, 1991, págs. 239-240.

28 Torres Villarroel, Visiones y visitas, pág. 314. 
de los compendios científicos de la época. Aunque el libro tiene algunos rasgos aún escolásticos y trata de asuntos como los duendes y otros seres invisibles, presenta también características propias de una nueva mentalidad caracterizada por la observación y la explicación científica ${ }^{29}$. Así pues, en la Anatomía taxonómica del mundo que presenta el autor, existe espacio para reflexionar sobre la corporeidad del individuo en unas Difiniciones de las partes sólidas y líquidas del cuerpo:

Pelos son unas partes disimilares que constan de corteza y médula, como está averiguado por el microscopio.

$[\ldots]$

Orina es una serosidad de los cuatro humores que contienen mucha sal, así fija como volátil, poco azufre y poca tierra. Esta y la mierda son las heces y la parte fecal de los alimentos, de modo que la naturaleza escoge lo útil y provechoso de los alimentos y, cogida la parte más balsámica, arroja lo inútil de ellos.

$[\ldots]$

Vigilia es el natural estado de nuestro cuerpo, por el cual nos ejercitamos a las sensaciones y movimientos.

Sueño es un vínculo de los sentidos exteriores por el cual son tan ligados e impedidos que no pueden ejercitar sus funciones y movimientos.

Insomnio es una operación del sentido interno que se hace por medio de una impresión en el órgano.

Estas son las más proprias afecciones y funciones del animal. Las demás que se hallan en los racionales tocan y pertenecen al alma. Yo procuraré dictárselas a vuestras mercedes otro día, porque ahora tenemos poco lugar y necesitan vuestras mercedes otros principios para su inteligencia ${ }^{30}$.

Extractamos únicamente algunas de un total más extenso, aunque el párrafo seleccionado es útil en varios sentidos para entender mejor el poema objeto de análisis. Debe señalarse, por supuesto, que aparece una referencia a la tan traída y llevada mierda, en el apartado de la orina, junto con heces y otro tipo de excrecencias que se deshechan por inútiles. Pero además, y esto es de gran interés, se alude a la tríada vigilia-sueño-insomnio desde un punto de vista material y orgánico, resultado de una observación e interpretación objetiva del funcionamiento del cuerpo humano. Es decir, cuestiones tradicionalmente rela-

29 Véanse las consideraciones expuestas en nota 7.

30 Diego de Torres Villarroel, Anatomía de todo lo visible e invisible, Salamanca, Antonio Villarroel, 1738, págs. 100-102. 
cionadas con el plano metafísico, religioso o filosófico pasan ahora a convertirse en algo propio del individuo en su dimensión material. De acuerdo con esto, tan orgánico es el sueño como el pelo (que se observa con microscopio), la vigilia, el insomnio o la propia mierda.

Esto nos parece de interés en relación al soneto porque sitúa su análisis en coordenadas que poco tienen que ver con el discurso idealizado, pero también se alejan un punto de los textos quevedianos. El sueño, al que se apela en el poema, no es algo relacionado con el alma, sino que forma parte de un estado físico caracterizado por la suspensión de las capacidades normales de los sentidos. Así pues, el penúltimo endecasílabo («haga usté cuenta que mi amor fue sueño»), de acuerdo con lo que el propio Villarroel conceptualiza en su Anatomía, debe entenderse como la superación de esa suspensión de los sentidos, de una alteración que impedía el correcto desarrollo y funcionamiento del individuo en su dimensión corporal e intelectual. Nada hay de animismo, neoplatonismo o metafísica cristiana en el poema, por supuesto. Pero tampoco se trata de una escritura al modo quevediano.

Importa subrayar el sentido del sueño porque, justamente, en el soneto el enfado o proceso de cambio de opinión se produce por un sueño del que se despierta. Esto es, por un reequilibrio terapeútico de ciertos desórdenes en la conducta del amado. Ello provoca que se pueda percibir, entender e interpretar la realidad de otro modo y, en virtud de ello, resulta absolutamente posible desterrar de los versos a la causante del desequilibrio enfermizo, quien había sido protagonista de excepción de la escritura poética en las centurias anteriores: la referencia al sujeto femenino.

Esta expulsión o destierro es resultado de un proceso de maduración individual que se desarrolla a lo largo de los dos primeros cuartetos. En el primero, se ubica el espacio desde el que se enuncia, en tanto que en el segundo se deja claro que el sujeto poético se desengaña tras entender que su sentimiento amoroso fue producido por un desorden del entendimiento: «Gracias a Dios, ya está desengañado / de aquella imagen falsa, cautelosa». Importa considerar al respecto que el «desengaño» en Villarroel está vinculado con un proceso de maduración y aprendizaje. Así se intuye en el poema mencionado. Pero se puede observar con mayor claridad en la Anatomía, obra preparada e impresa con simultaneidad a los Juguetes de Talía, entretenimientos del numen ${ }^{31}$, como

\footnotetext{
31 Los Juguetes se estampan el mismo año en que Antonio Villarroel, primo del autor, publica la Anatomía de todo lo visible e invisible (1738) del Piscator, compendio en prosa en que se ofrecen diversas interpretaciones sobre distintos aspectos de la realidad, con un variable grado de racionalidad y cientifismo. Ambas obras, tan distintas en su temática y en su conformación genérica, se concibieron y diseñaron simultáneamente, como lo prueba que se editasen y salieran al mercado al mismo tiempo y que incluso compartan el
} 
ya se indicó en las páginas previas. Así ocurre, por ejemplo, en el siguiente pasaje:

Hasta hoy había confesado a los filósofos y astrólogos, bien que con algún temor, la colocación de esferas del uno y otro mundo elemental y celeste; pero ya en esta caminata me he desengañado. Y huyendo de la opinión de todos, he de fijar sistema nuevo, más fácil y más perceptible a la vista, porque no hay duda que todo cuanto se pueda borrar y destruir de líneas imaginarias, orbes fantásticos, deferentes y ecuantes supuestos hará más inteligible y menos enredosa la noticia de este bellísimo Globo ${ }^{32}$.

El desengaño y la interpretación cabal y nueva de la realidad permiten afirmar entonces al sujeto de la enunciación que la realidad percibida inicialmente no es otra cosa sino una imagen falsa de lo que se pensó intuir: «Gracias a Dios, ya está desengañado / de aquella imagen falsa, cautelosa». Y en este sentido, la alusión al término «imagen» tampoco nos parece casual en el verso 4 del soneto, pues conviene tener en cuenta que esta noción posee un sentido ligado a lo científico o a lo positivo en Torres Villarroel.

Así, y recurriendo de nuevo a su Anatomía de todo lo visible e invisible, hay un pasaje en el que discute el autor sobre la Esfera armiliar, instrumento del que se valen los astrólogos para el estudio de la bóveda celeste, como expone el autor:

Suelen tener los astrólogos, para el conocimiento de la división imaginaria del cielo, otro instrumento que llaman Esfera Armiliar o de argollas. En esta no aparecen más que los diez círculos y un eje que pasa desde el Polo Ártico por el centro de la Tierra hasta el Polo Antártico (pág. 149).

Después de explicar y esclarecer su sentido, se establece una distinción entre «Imágenes» y «Estrellas», en virtud de la cual «la Imagen no es otra cosa que cierta multitud de Estrellas fijas que con su disposición forman una figura como de Toro, Lobo, Carnero, etc.» (pág. 150).

De acuerdo con esto, la «imagen» que se había formado o percibido de la amada funciona igual que la que se observa en la bóveda celeste desde la tierra, punto en que se sitúa el observador. Conforme a ello, y tratándose de una contemplación individual y no de una verdad revelada e inamovible, la percepción de

mismo texto admistrativo y legal de la aprobación para ser impresa, otorgada en veinticuatro de junio de 1738. Sobre esto véase García Aguilar, Entretenimientos del numen, pág. 103.

32 Torres Villarroel, Anatomía, pág. 131. La cursiva es nuestra. Todas las referencias responden a esta edición. 
la amada puede alterarse y cambiar, como así ocurre, después de un proceso de desengaño o conocimiento. Todo ello produce un efecto muy concreto en el ánimo de quien se expresa en soneto: el enfado. Esta impresión molesta y desagradable del ánimo es lo que induce al sujeto de la enunciación a manifestar un desdén absoluto hacia la amada, lo que le lleva a expulsarla del cuerpo del poema, del espacio de la enunciación. Supone, en fin, una ruptura con el discurso y la sentimentalidad lírica tal y como se concebía desde largo tiempo atrás.

El lugar al que se envía a la amada en un soneto como este es muy clarificador de que existe una sentimentalidad lírica distinta en la poesía torresiana; o al menos constata que el repertorio poético es lo suficientemente amplio como para acoger una manera diferente de formular el sentimiento, en donde no sólo no es necesaria la mujer, sino que se le insta, explícitamente, a desaparecer del cuerpo referencial del poema. Sin embargo, esta exclusión no es el objeto de nuestra indagación ni el motivo del presente monográfico, pues lo que de verdad se persigue es indagar en la relación que pudiera existir con una manera de entender y formular la razón en el siglo XVIII. Cabría preguntarse, por tanto, si la razón tiene alguna incidencia en este cambio o, siquiera, si hay espacio para ella en el cuerpo del soneto.

Nuestra hipótesis es que la razón se convierte, justamente, en la catalizadora de los cambios que se producen en la lírica torresiana. Es más, creemos que un poema como este puede interpretarse a la luz de una obra de tantísima relevancia como el Teatro crítico universal de Feijoo, que se considera un punto de inflexión en el paso hacia lo que se ha denominado Ilustración española.

El Teatro crítico, como ya mencionamos al comienzo, no pasó inadvertido para Torres Villarroel, quien le dedica, al menos, dos textos críticos ${ }^{33}$. Y aunque entre ambos autores había motivos para la confrontación, debido a las ideas tan distintas que tenían sobre cuestiones como la astrología, también existían espacios de confluencia, por ciertas opiniones compartidas. Así ocurría, por ejemplo, con la similar apreciación que ambos tenían sobre los desmanes de los médicos y la excesiva superstición con que se trataban algunos males y enfermedades, entre ellas el amor. Por estos puntos de encuentro entre ambos es por lo que nos interesa reflexionar, como ya anticipamos al comienzo del trabajo, acerca de algunas de las cuestiones que expone Feijoo en los dos últimos discursos del volumen séptimo de su Teatro y conectar dichas cuestiones con ciertos aspectos del soneto al que nos venimos refiriendo.

En las Causas del amor (TCU, VII, d. XVI) indaga Feijoo sobre todo aquello que influye en el despertar de la pasión amorosa. Y en conexión con esto, cons-

33 Véase nota 8. 
truye el último de los discursos, con que se cierra el libro. Partiendo del referente clásico de los Remedia amoris y de toda la tradición anterior, pretende demostrar lo erróneo de dos premisas contrarias y extremas que son asumidas sin cuestionamiento: la idea de que el amor es una pasión incurable y, en el polo opuesto, la opinión de quienes consideran que su curación es muy sencilla. Frente a ello, Feijoo plantea que es posible curar la pasión amorosa, aunque no es una tarea fácil: «Juzgo absolutamente curable la pasión amorosa [...] su curación es muy difícil» (§ II, 6). Para demostrarlo comienza criticando en los primeros capítulos las deficiencias y flaquezas del texto ovidiano, señalando racional y críticamente las inconsistencias de los argumentos aducidos en el Ars amandi.

Desecha entonces los remedios naturales, precisando que entiende la pasión amorosa como enfermedad «del amor delincuente, porque el amor santo antes es salud» (§ II, 9). Por tanto, tiene claro Feijoo que el amor curable es el que forma parte consustancial de lo humano y terreno; nada que ver con antiguas pasiones de corte más espiritual, idealizado y sublime. Afirma, por ello, que su «principal mira será la curación del amor impuro» (§ II, 9). Critica remedios médicos como las sangrías, de tanto éxito y aceptación en épocas pasadas, aduciendo argumentos tan racionales y objetivos como que «con la sangre nueva subsiste la misma textura de las fibras del cerebro» (§ II, 11). En esta misma línea se descartan todo tipo de purgantes, dado que «el amor no reside en la flema, en la melancolía, en la cólera o en algún otro humor extraíble por catárticos, diuréticos o sudoríficos» (§ II, 12).

Del ámbito de lo médico («físicos sueños») se pasa a remedios «más autorizados» (§ II, 13). Vuelve entonces a Ovidio para plantear y refutar diversas soluciones prácticas. La primera es «la ausencia del objeto amado» (§ II, 13) (Magnum iter, ad doctas proficisci cogor Athenas, / Ut me longa gravi solvat Amore via), a la que Feijoo concede una efectividad limitada. Lo mismo ocurre con el recurso de «lidiar contra la pasión a los principios» (§ II, 16) (Principis obsta). La tercera solución es ocuparse en negocios mundanos que faciliten la desatención del amor, aunque aduce Feijoo los ejemplos de Marco Antonio y Enrico el Grande para constatar que sus ocupaciones militares no les hicieron olvidar a sus respectivas amantes. A ello se suma que no está en la mano de todos poderse ocupar de tales o cuales negocios distractores. El cuarto remedio sobre el que reflexiona Feijoo, en la estela de Ovidio, es pensar en los defectos de la amada. Sin embargo, señala el ilustrado, muy juiciosamente, que aunque nadie está libre de defectos, este remedio «apenas sirve a alguno, salvo que la pasión sea débil o los defectos enormes» (§ II, 24); además, apostilla que tales defectos deberían ser advertidos muy prontamente, «porque quien con el conocido contrapeso de esos defectos empezó a amar mucho, proseguirá en amar, 
por más que piense en ellos» (§ II, 24). Finalmente, a partir del capítulo VIII, se abandona la acerada crítica contra el autor latino y se organizan los argumentos de la propuesta de Feijoo: «Vista ya la ineficacia o inutilidad de todos los remedios que hasta ahora se han discurrido para la fiebre del amor, resta que propongamos el de nuestra invención» (§ II, 30).

Aduce entonces diferentes soluciones parciales y varias reflexiones, hasta concluir que el mejor remedio contra el amor es el que proviene de la capacidad del individuo para racionalizar los afectos y derivarlos hacia afanes intelectuales distintos. En palabras de Feijoo: «se puede turbar, corregir o mitigar el movimiento que da a las fibras del ce[le]bro la imaginación de un objeto que excita tal pasión con la imaginación de otro objeto que excite otra pasión diferente» (§ II, 36). Lo que se recomienda al amante, en palabras llanas y lisas, es que piense en otra cosa. Es decir, que mande lejos de su imaginación al objeto amado y opte por una pasión diferente. Nada distinto a lo que hace Torres Villarroel en su poema.

De su análisis contrastivo entre el texto de Feijoo y el referente ovidiano concluye Vicente Cristóbal que «poniendo a debate su razón con la autoridad de un clásico y dejando al descubierto la sinrazón de la autoridad, se nos manifiesta como un ilustrado de su tiempo ${ }^{34}$. Sería arriesgado, y probablemente inexacto, aplicar estas mismas palabras a Torres Villarroel. Sin embargo, no nos parece aventurado señalar que algo muy similar ocurre en el soneto que hemos analizado, en donde la sentimentalidad lírica se configura a partir de una superación racional y crítica de los modelos asumidos. Justo lo que hace con esta pasión en sus Sonetos amorosos, que poco o nada albergan del amor idealizado de antaño, y sí mucho de la racional sentimentalidad de hogaño.

\section{A modo de conclusión}

La lírica del Siglo de Oro tiene su señal de identidad más distintiva en la poesía de carácter amoroso, caracterizada por la idealización del objeto femenino y la voz hegemónicamente masculina, siempre sufriente, que se eleva y sublima en virtud de este padecimiento. Por ello, la mujer es la donna angelicata que propicia este viaje elevador y que se convierte en mensajera o intermediaria entre la esfera material del mundo imperfecto en que vive el amante y la perfección ideal de aquella parcela de realidad a la que aspira el poeta.

\footnotetext{
34 Vicente Cristóbal, «Los Remedia amoris de Ovidio en la visión crítica del P. Feijoo», Cuadernos de Filología Clásica: Estudios latinos, 1 (1991), págs. 233-240, pág. 236.
} 
En este discurso, el soneto procura una plataforma que permite, por su concatenación y agrupación en las rime sparse la construcción de un itinerario que tiene su plasmación más específica en la forma canzoniere. Petrarca enfatiza la imposibilida de su amor en la segunda parte de su Canzoniere, dirigido a Laura in morte. La aniquilación del objeto femenino supone su negación material y su plena afirmación espiritual. Al margen del mundo y segura en el espacio de lo etéreo, Laura será el símbolo de la exclusiva amada ideal que permite la elevación del afligido yo poemático. Toda ella es, en su mismo simbolismo onomástico (aura/laurel), luz radiante, espíritu ideal, soplo inasible e imagen poética. Todo un paradigma en sí mismo que se funde (y a veces confunde) con un gusto literario y unas prácticas poéticas que tienen que ver con la asunción de una teoría neoplatónica sobre el amor de acuerdo con la cual la sentimentalidad se convierte en toda una filografía relacionada con complejas ideas filosóficas (en donde el amor está vinculado a una metafísica y una epistemología propia) y sociales que permiten justificar o sustituir las carencias guerreras de la clase nobiliaria con adornos y destrezas intelectuales como la poesía; en suma, un adorno del perfecto cortesano.

En la lírica aurisecular española, las características de esta filografía procedente de Italia permiten ahormar con relativa facilidad las inquietudes de la poesía religiosa. De ahí, por ejemplo, que un autor como san Juan de la Cruz pueda dar rienda suelta a sus inquietudes místicas a través de las formas y modos del discurso amoroso, pues la espiritualidad neoplatónica encajaba sin dificultad con ideas como las de verdad, bien o belleza. Con el cambio de siglo estas formas evolucionan en distintas direcciones, pues el petrarquismo en sentido estricto se descompondrá o desgajará de algunos de sus componentes o potencialidades, los cuales serán aprovechados a conveniencia por distintos autores. Así, un escritor como Fernando de Herrera explotará el fondo neoplatónico del discurso para enfatizar valores simbólicos como la luz, y no ya la personificación del objeto femenino. Góngora, por su parte, subrayará el valor de la formalización textual per se en detrimento de una temática y unos modos heredados, que son entendidos como herramientas e instrumentos al servicio de la construcción ficcional, enfatizando y revelando así la contraposición entre los planos del ser y el decir ${ }^{35}$. Desde una perspectiva diferente, este discurso y esta sentimentalidad retórica serán moldes muy explotados por el confesionalismo del Fénix. Por su parte, un autor como Quevedo recurrirá todavía a un petrarquismo ortodoxo, desde el punto de vista temático y formal, para sus sonetos

35 Claramente ejemplificado en su «Manda amor en su fatiga / que se sienta y no se diga, / pero a mí más me contenta / que se diga y no se sienta». 
a Lisi; aunque esto no será obstáculo para que cultive una contraimagen de lo femenino en muchos de sus poemas misóginos y satíricos hacia las inconsistencias y defectos de las mujeres.

Estas modulaciones hacen que a medida que avanza el siglo XVII la exclusiva ligazón entre argumento amoroso y expresión de una sentimentalidad lírica vaya ampliándose, dejando espacio para otras formulaciones, de carácter erótico, en donde tendrán cabida temas anejos como la pasión, el desengaño o la corporeidad. Toda esta heterogeneidad poética encuentra un cauce idóneo de expresión en los volúmenes de varias rimas, soporte habitual para la difusión de la poesía áurea.

Se suele aceptar que Torres Villarroel es un autor que continúa en sus poemas muchos de los modos y formas de la poesía aurisecular ${ }^{36}$. Y ello es cierto si se atiende a la reiteración de formas estróficas y a las referencias directas a autores como Lope, Góngora o Quevedo, presentes implícita o explícitamente en muchas de sus composiciones. El recorrido por los Sonetos amorosos de los Juguetes impresos en 1738 permite apreciar las líneas de continuidad, sobre todo en el ámbito temático-formal, entre la sentimentalidad del XVII y la del primer tercio del XVIII; pero también arroja luz sobre las notorias diferencias entre una y otra propuesta.

Del análisis particular de las distintas piezas, así como de su lectura secuencial, se colige que la lírica barroca era conocida y funcionaba como referente para la escritura de Torres Villarroel, quien se valía de ella, fundamentalmente, como cantera en la que buscar imágenes, motivos, tópicos o moldes genérico-estróficos y patrones dispositivos. Sin embargo, todos estos elementos se someten a una relectura actualizadora que los dota de nuevos sentidos. Tal relectura rebaja la idealización hasta situar a los poemas en coordenadas terrenas, operación esta en la que cobra gran importancia lo escatológico; cambia la ficción de confesionalidad privada por una notoria exhibición de las dotes versificatorias del escritor, quien apela a una amada cambiante y cada vez más cercana, en la doble dimensión del espacio (histórico) y de la cronología (coetánea); despoja a la lírica amorosa del hálito de sacralidad supramundana y trascendencia, de modo que el amor poético se contamina en los versos de prácticas de sociabilidad literaria en las que lo amoroso y lo sentimental son, por medio del chichisveo, juego de ingenio y galanteo literario. Por todo ello, el requerimiento de amor y el diálogo íntimo que ello provocaba en el sujeto poético barroco no se ponen, como en la centuria anterior, al servicio de un perfeccionamiento y elevación individual. Antes bien, se convierten en el vehículo idóneo para la

36 Véase nota 2. 
reivindicación de las dotes literarias y, por ende, espejo que muestra el mejoramiento en el oficio de las letras.

En el ámbito de la conflictiva individualidad de la enunciación amorosa se parte de una situación de enamoramiento que deriva, por efecto de un cambio intelectual, mental y emocional hacia un desapego absoluto con respecto al objeto amado, que en modo alguno es entendido ya en términos de trascendencia. Este cambio tiene mucho de curación racional, al modo en que plantea Feijoo sus Remedios de amor, que no son sino un ars amandi adecuado a los sujetos de un mundo en el que la razón domeña y gobierna al corazón.

Es plausible asumir que Torres Villarroel conociera esta obra de Feijoo, igual que conocía anteriores entregas de su Teatro crítico. Además, habiéndose publicado dos años antes de imprimirse la Anatomía y los Juguetes, el Piscator no solo podría haberla leído, sino incluso haber incorporado a su escritura algunos de los planteamientos del ilustrado, como hemos tratado de señalar en nuestro trabajo. En ese caso, Feijoo y Torres Villarroel no serían islotes distintos y distantes en un piélago de cambios.

El maestro François Lopez se valía de ambas figuras, entendidas como diametralmente opuestas, para explicar las paradójicas peculiaridades del siglo XVIII español, afirmando que «l'âge de Feijoo fut aussi celui de Torres Villarroel et l'on ne peut comprendre ce siècle si l'on ne s'efforce d'apprécier les vigoureux contrastes culturels qui furent sa chair, sa couleur et sa vie ${ }^{37}$. Una misma época y compartidos espacios facilitan, las más de las veces, las coincidencias por encima de las diferencias, sean estas pretendidamente buscadas o casualmente encontradas por la confluencia de puntos de vista que se comparten en un mismo contexto epocal. Y acaso sea algo de esta contaminación la que se deja sentir en la poesía amorosa de Torres Villarroel, apegada en buena parte de su forma externa a patrones auriseculares, pero empapada en su sentido del sentimiento y la razón preludiadas por los nuevos aires de cambio ilustrado.

37 François Lopez, Juan Pablo Forner et la crise de la conscience espagnole au XVIII siècle, Burdeos, Institut d'Études Ibériques et Ibéro-américaines de l’Université de Bordeaux, 1976, pág. 64. 